\title{
PERSEPSI VISUAL PENYANDANG TUNAGRAHITA: STUDI DESKRIPTIF OLAH GAMBAR PADA SEKOLAH LUAR BIASA YAYASAN AMAL MULIA
}

\author{
Arief Ruslan ${ }^{1}$ \\ Arif Nur Hidayat ${ }^{2}$ \\ Archita Desia Logiana ${ }^{3}$
}

Diterima Mei. o3, 2021; Disetujui Mei. 29, 2021.

\begin{abstract}
Abstrak: Penyandang tunagrahita atau yang disebut sebagai mental retardation secara umum dikategorikan dalam keterbelakangan mental. Beberapa penelitian melihat bahwa salah satu konsep pembelajaran yang efektif adalah melalui bentuk visual dan audio visual. Tetapi dalam pendidikan menggambar penyandang tunagrahita ternyata mempunyai pola yang berbeda dalam menanggapi makna visual. Persepsi visual terbangun pada konsep motorik kasar dalam mengolah gambar-gambar tidak selalu dilakukan dengan mudah. Penelitian ini dibangun dengan metodologi kualitatif deskriptif untuk melihat dan mendeskripsikan bentuk dan model gambar apa yang mudah hingga sulit untuk diolah. Pengambilan data penelitian ini adalah melalui anak-anak tunagrahita sedang dari Sekolah Luar Biasa Yayasan Amal Mulia dengan mengolah gambar dalam tiga bentuk yakni garis, model bentuk, dan kombinasi bentuk. Temuan awal dalam penelitian ini adalah, siswa tunagrahita mempunyai kesulitan dalam menggambar bentuk yang tidak lurus atau solid, seperti lengkungan dan lingkaran, walaupun demikian para siswa masih dapat mengolah sesuai arahan dengan waktu yang tidak terlalu lama.
\end{abstract}

Kata Kunci: tunagrahita; menggambar; persepsi visual; model bentuk; pendidikan

Abstract: People with tunagrahita are generally categorized as mental retardation. Several studies have seen that one of the effective learning concepts is through visual and audio-visual forms. But in drawing education, mentally retarded persons have different patterns in response to visual meaning. Visual perception is built on coarse motor concepts in processing images which are not always done easily. This research is developed with a descriptive qualitative methodology to see and describe what forms and image models are easy to difficult the draw process. Retrieval of the research data

${ }^{1}$ Arief Ruslan adalah staff pengajar pada Fakultas Ilmu Komunikasi Universitas Budi Luhur, Jakarta.

${ }^{2}$ Arif Nur Hidayat adalah staff pengajar pada Fakultas Ilmu Komunikasi Universitas Budi Luhur, Jakarta.

${ }^{3}$ Archita Desia Logiana adalah staff pengajar pada Fakultas Ilmu Komunikasi Universitas Budi Luhur, Jakarta. e-mail : arief.ruslan@budiluhur.ac.id

e-mail: arif.nurhidayat@budiluhur.ac.id

e-mail: architateach@gmail.com 
was through mentally retarded children from the Extraordinary School of the Amal Mulia Foundation by processing images in three forms, namely lines, shape models, and combinations of shapes. The preliminary findings in this study were that students with mental retardation had difficulties in drawing shapes that were not straight or solid, such as curves and circles, even though the students were still able to process according to directions in not too long.

Keywords: mental retardation; drawing; visual perception; shape models; education

\section{Pendahuluan}

Kesulitan menampilkan hasil pembelajaran dianggap sebagai salah satu yang paling penting di bidang pendidikan. Pendidikan khusus yang difokuskan kepada seseorang yang mempunyai kecacatan mental menyebabkan munculnya pendidikan spesialis dalam berbagai ketidakmampuan belajarnya tersebut (Alenizi, 2019). Hal ini menunjukkan bahwa pendidikan untuk para masyarakat penyandang disabilitas tidak ditemukan yang cocok melalui bentuk tahap normal dalam sistem pendidikan. Pendidikan khusus umumnya disukai bila kebutuhan pendidikan individu tidak dapat dipenuhi oleh kelas normal atau sekolah terkait jenis dan derajat keterbelakangan mereka (Erim, 2017).

American Psychiatric Association (2013), mengungkapkan anak tunagrahita disebut sebagai seseorang yang memiliki IQ di bawah rata-rata. Klasifikasi individu tunagrahita dibagi menjadi tiga bagian, yaitu tunagrahita ringan dengan rerata IQ 50-70, tunagrahita sedang dengan rerata IQ 25-50, dan tunagrahita berat dengan IQ dibawah 25. Secara umum, ciri-ciri yang paling utama dari anak tunagrahita adalah sulitnya diajak berkomunikasi secara normal dan perlunya proses yang lama dalam pembelajaran terhadap halhal yang baru. Delpie (2005) mendefinisikan tunagrahita sebagai mental retardation yang mempunyai keterbelakangan dan kekurangan dalam adaptasi tingkah laku serta penyesuaian diri dengan lingkungannya sesuai taraf usia yang telah dicapai seorang anak.

Beberapa penelitian tentang pembelajaran khusus dalam pengenalan nilai-nilai pendidikan juga banyak dilakukan. Louk \& Sukoco (2016) melakukan penelitiannya dengan memberikan pembelajaran audio visual untuk melihat dan memahami karakteristik serta motorik kasar siswa tunagrahita. Darnanta, et al., (2020) meneliti dengan merancang media pembelajaran matematika melalui interaktif dipadukan dengan konsep gamification, yaitu penerapan elemen desain berbasis game dan konsep dalam pembelajaran menggunakan prinsip permainan. Penelitian tersebut memperlihatkan proses integrasi melalui bentuk game berpikir, desain game, dan game mekanik yang dianggap dapat menumbuhkan motivasi untuk belajar dan mengubah perilaku siswa menjadi lebih baik. Alenizi (2019) melihat terjadinya kesulitan pembelajaran di antara peserta didik dengan ketidakmampuan belajar dalam pengajaran dengan strategi dan bentuk yang berbeda (strategi multi-indera / metode tradisional), dalam pembelajaran bahasa Arab.

Penelitian pembelajaran khusus yang menitikberatkan bentuk teknis untuk penyandang tunagrahita juga bermunculan, salah satunya melalui teknis visual. Dalam studi awal, Webb (1972) menemukan bahwa individu dengan retardasi 
mental (tunagrahita) menderita sensitif terhadap stereogram atau titik acak sebagai individu yang mempunyai keterbelakangan mental. Individu tersebut dengan dan tanpa keterbelakangan mental mampu menunjukkan secara akurat kehadiran persegi, salib, atau segitiga dalam stereogram. Webb menyimpulkan itu sistem visual yang bertanggung jawab untuk pemrosesan binokuler beroperasi dengan cara yang sama di dua kelompok. Eksperimen yang dilakukan oleh Fox dan Oross (1988) menggunakan tujuh bentuk yaitu, persegi, segitiga, lingkaran, persegi panjang vertikal, persegi panjang horizontal, berlian, dan bintang. Temuan dari eksperimen tersebut memperlihatkan kesalahan-kesalahan yang dibuat atas kesamaan dari bentuk-bentuk yang digunakan.

Melalui metode persepsi visual, Erim (2017) melihat melalui pendidikan seni rupa, anak tunagrahita memperoleh banyak keterampilan, seperti kontak mata, koordinasi tangan-mata melalui penggunaan bahan, dua tangan secara simultan berkoordinasi, dan belajar untuk membantu dan berbagi, sebagai tambahan akuisisi keterampilan motorik. Persepsi visual merupakan penerimaan fungsi sensorik dan kognitif dari rangsangan visual dan komponen kognitif. Pembelajaran visual berhubungan dengan perhatian visual, memori, perbedaan konsepsi dan perbedaan visual persepsi subjek (stabilitas bentuk, bentuk/model, dan dasar) dan tempat kognisi (Garje, et al., 2015). Selain itu, persepsi visual tumbuh dengan mengandalkan indra di mana anak melihat objek, membedakannya, dan kemudian menentukan lokasinya dalam operasi kognitif yang akan dimasuki informasi dari lingkungan melalui indera dan sederhana dan definisi langsung dari persepsi dilihat sebagai metode dalam menjelaskan informasi yang diterima. Studi empiris telah berfokus pada peran visual persepsi dalam proses pembelajaran pendidikan (Pieters, et al., 2012). Berbagai penelitian menentukan program yang efektif tidak hanya dalam peningkatan persepsi visual tetapi juga indera lain peserta didik dengan pembelajaran kesulitan (Mahmoud \& Al nahdi, 2014).

Pembelajaran melalui gambar dan paduan antara gambar dengan suara merupakan hal yang paling menarik sebagai landasan pendidikan untuk para penyandang tunagrahita. Salah satu yang peneliti lihat adalah Sekolah Luar Biasa Yayasan Amal Mulia (SLBYAM), di wilayah Jakarta Selatan. SLBYAM menampung anak tunagrahita mencapai sekitar 30 orang dengan tingkatan yang berbeda yakni ringan dan sedang. Para pendidik memberikan pembelajaran kepada anak-anak berkebutuhan khusus dengan berbagai macam. Beberapa pengajar untuk anakanak tunagrahita menyebutkan bahwa proses pembelajaran membutuhkan proses yang perlahan dan panjang. Ubaidillah (2019) mengungkapkan dalam proses pembelajaran, siswa tunagrahita diberikan dengan bentuk pembelajaran visual sebagai tahap pengenalan tanda, seperti huruf, gambar, dan bentuk-bentuk visual lainnya.

Melalui observasi, peneliti melihat pembelajaran pengenalan bentuk melalui gambar yang dilakukan oleh pendidik seringkali terjadi perbedaan pandang, komentar tentang sulitnya melakukan olah gambar, dan tidak memahami gambar yang dihadirkan berbeda bentuk walaupun sama objeknya. Hal tersebutlah yang membuat peneliti ingin mengkaji bentuk gambar seperti apa yang mudah serta sulit dilakukan melalui olah gambar oleh para penyandang tunagrahita. Melalui analisis deskriptif visual, tujuan penelitian ini untuk mendapat gambaran kemampuan pemahaman, model kesulitan, serta bentuk yang paling mendasar dalam olah gambar yang mudah dikuasai. 
Arief Ruslan'

Arif Nur Hidayat ${ }^{2}$

Archita Desia Logiana ${ }^{3}$

\section{Metode Penelitian}

Penelitian ini menggunakan paradigma konstruktivisme. Penafsiran konstruktivis dideskripsikan sebagai interpretivisme, yaitu melihat serta memahami para individu dalam memahami dunia tempat mereka hidup dan bekerja (Mulyana, 2018). Teknik Analisis dan penyajian data dalam penelitian kualitatif dimulai dengan menyiapkan dan mengorganisasi data, yang kemudian mereduksi data tersebut menjadi tema melalui proses pengodean dan peringkasan kode. Selanjutnya, menyajikan data dalam bentuk bagan, tabel, atau pembahasan (Creswell, 2014).

Analisis data menggunakan deskriptif kualitatif menggunakan metodologi visual. Metodologi visual digunakan untuk memahami dan menafsirkan gambar dan termasuk fotografi, film, video, lukisan, menggambar, kolase, patung, karya seni, grafiti, iklan, dan kartun (Barbour, 2014). Metodologi visual adalah hal baru dan baru pendekatan penelitian kualitatif yang berasal dari metode tradisional etnografi yang digunakan dalam antropologi dan sosiologi (Glaw, et al., 2017).

Penelitian ini mengambil data melalui gambar yang diolah oleh anak-anak penyandang tunagrahita sedang, yakni 15 anak. Model gambar yang diberikan dengan tiga klasifikasi, yaitu gambar garis, gambar satu bentuk, dan gambar model dengan penggabungan bentuk-bentuk. Setelah data terkumpul, interpretasi hasil dibahas dan diskusi dibuat berdasarkan hasil penelitian.

\section{Hasil dan Pembahasan}

Peneliti mengumpulkan siswa penyandang tunagrahita dengan dua kelompok, yakni usia 7-10 tahun sebanyak sepuluh siswa, dan 11-15 tahun sebanyak lima siswa. Setiap siswa diberikan dengan perangkat gambar seperti kertas yang be-
Persepsi Visual Penyandang Tunagrahita: Studi Deskriptif Olah Gambar Pada Sekolah Luar Biasa Yayasan

Amal Mulia

rukuran A4, papan gambar serta pensil dan penghapus. Pelatihan gambar dalam penelitian ini dilakukan pada pelataran SLBYAM untuk dapat menampung para siswa dalam mengolah gambarnya. Walaupun penelitian ini dilakukan pada pelataran, prosesi penggambaran tidak menjadi kendala yang signifikan. Selain itu pula, dengan adanya kedekatan antara siswa memberikan momentum terhadap komunikasi yang lebih terjalin satu sama lain karena kedekatan posisi mereka.

Pada penelitian sebelumnya, Fox dan Oross (1988) menguraikan dengan tujuh elemen bentuk garis untuk melihat persepsi visual anak tunagrahita. Pada penelitian ini, peneliti menggunakan elemen bentuk garis yang dipadu dengan elemen bentuk lain sebagai analisis baru terhadap persepsi visual anak tunagrahita, khususnya di SLBYAM. Proses penggambaran ini dilakukan selama empat jam penuh dengan klasifikasi model sebagai berikut:

1. Garis : garis lurus, lengkung, dan acak

2. Model bentuk: segitiga, segiempat, lingkaran, dan lonjong (elipse)

3. Model kombinasi: mata, bentuk wajah, gua, dan kelinci sederhana

Peneliti yang terlibat dalam kegiatan ini dituntut untuk memanfaatkan materi dengan baik serta membuat suasana yang tidak terlalu kaku seperti mebangun komunikasi seperti dialog, membangun humor-humor kecil, bercanda, serta memotivasi peserta dalam penelitian berlangsung. Programnya ini dibuat tidak terlalu melelahkan bagi peserta didik sehingga waktu istirahat yang sesuai dapat dipertahankan pelaksanaan program yang efektif.

Dalam program pelatihan ini dibagi menjadi dua sesi dengan masing-masing 
durasi 40 menit dengan 20 menit istirahat untuk melepaskan kelelahan, minum dan makan, serta kebutuhan penting alamiah peserta didik. Sesi pertama diberikan waktu 120 menit untuk menggambar model garis dan model bentuk. Pada sesi kedua juga diberikan waktu 120 menit untuk menggambar model kombinasi, hal tersebut mengingat bahwa model kombinasi mempunyai kompleksitas bentuk yang tinggi.

Tinjauan penilaian dari media pembelajaran meliputi aspek-aspek proses menggambar yang meliputi psikologis, akurasi material, dan prinsip visual (Pardimin \& Widodo, 2017). Pendidikan seni visual sebagai proses yang membantu anak-anak, biasanya berkembang dan terbelakang mental untuk bersosialisasi melalui kerja kelompok, untuk mengekspresikan dunia batin mereka sendiri (Erim, 2017). Pada aspek akurasi material melihat stabilitas dan kesesuaian penggambaran. Untuk prinsip visual sebagai instrumen dalam melihat pemahaman gambar-gambar yang sudah diolah. Aspek psikologis meliputi kejadian-kejadian baik gestur tubuh serta komunikasi yang terjalin pada pembelajaran terjadi. Sedangkan kecepatan gambar sebagai instrumen tambahan peneliti untuk melihat kemampuan daya tangkap peserta tunagrahita.

\section{Model Garis dan Bentuk}

Pada sesi yang pertama para siswa menggambar model garis dengan spesifikasi lurus vertikal dan horizontal, penggabungan antara lurus vertikal dan horizontal, lengkung ke atas dan ke bawah, dan selanjutnya penggabungan lengkung ke bawah dan ke atas. Penggambaran bentuk garis lurus sepertinya tidak terlalu menyulitkan siswa kelompok 1 dan kelompok 2 untuk mencapainya, bahkan memberikan kesenangan-kesenangan seperti tertawa, saling bercanda satu sama lainnya. Tetapi pada garis lurus campuran memberikan sedikit kesulitan bagi kelompok 1 dalam penggambaranya. Beberapa komentar dan pertanyaan seringkali didapati peneliti seperti meminta untuk mengulanginya kembali, walaupun demikian, penggambaran kembali tidak memakan waktu yang cukup lama.

Kesulitan penggambaran pada model garis terjadi ketika instruktur (peneliti) membuat garis lengkung. Garis lengkung tersebut membuat para siswa kesulitan dengan komentar seperti "itu gimana?" atau "susah juga". Sepertinya model garis lengkung yang dihadirkan tidak menjangkau pemahaman garis utuh sebagaimana garis lurus yang solid. Garis lengkung yang mempunyai bengkokan agak membuat keheranan para siswa. Terlebih lagi pencampuran antar garis lengkung yang dihadirkan yakni lengkung ke atas dan ke bawah membuat para siswa sangat kesusahan. Penggambaran percampuran ini

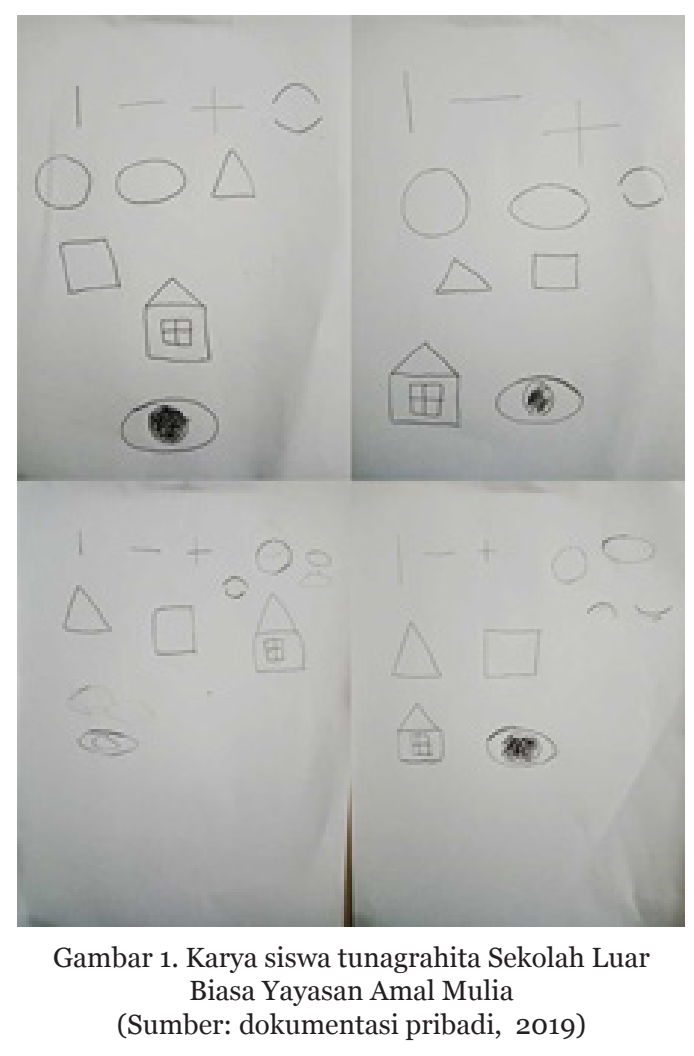


Arief Ruslan'

Arif Nur Hidayat ${ }^{2}$

Archita Desia Logiana ${ }^{3}$

memakan waktu cukup lama dan harus mengulang-ulang kembali untuk dapat diselesaikan.

Penggambaran model bentuk dilakukan sesi selanjutnya setelah penggambaran model garis. Melalui kertas yang sudah diberikan, siswa diinstruksikan untuk mengikuti gambar yang dilakukan oleh peneliti. Gambar model bentuk pertama adalah gambar segitiga. Gambar segitiga dilakukan dengan tahapan garisgaris secara terpola, yakni penggambaran dilakukan dengan menghubungkan garis satu dengan garis lainnya. Pada model gambar tersebut, tidak terjadi kesulitan yang besar bagi kedua kelompok. Begitu pula pada garis segiempat dapat dilakukan sesuai dengan bentuknya (S), dan tidak memakan waktu yang lama untuk dapat menyelesaikannya. Melalui gambar garis yang dihadirkan dalam bentuk segitiga dan segiempat, tidak terjadi lonjakan yang signifikan seperti garis lengkung. Komentar ataupun pertanyaan-pertanyaan seringkali diujarkan pada konteks yang berbeda. Persepsi visual pada gambar segitiga dan segiempat oleh siswa setidaknya mudah dipahami dan dicermati dengan baik, dan juga mereka mampu menjelaskan bentuk-bentuk tersebut dengan mudah.

Pada tahap penggambaran lingkaran dan lonjong, peneliti mendapati bahwa gambar model bentuk ini menjadi bagian yang paling susah untuk dilakukan oleh siswa kelompok 1. Penggambaran ini memakan waktu yang cukup lama dan harus mengulanginya beberapa kali. Penggambarannya pun tidak sempurna, yakni terjadinya tekanan gambar, arsiran, dan menghapus dengan alat penghapusan untuk menggambarnya kembali. Stabilitas gambar seringkali tidak sesuai dengan gambar yang diarahkan, sehingga garis-garis yang digambarkan siswa tidak konsisten seperti antara lingkaran dengan lonjong hampir sama satu dengan yang lainnya.
Persepsi Visual Penyandang Tunagrahita: Studi Deskriptif Olah Gambar Pada Sekolah Luar Biasa Yayasan Amal Mulia

Tabel 1. Stabilitas dan Persepsi Gambar pada Bentuk Model

Sumber: data pribadi 2019

\begin{tabular}{|l|l|l|l|c|}
\hline $\begin{array}{l}\text { Bentuk } \\
\text { Model }\end{array}$ & \multicolumn{2}{|l|}{ Stabilitas gambar } & \multicolumn{2}{l|}{ Persepsi } \\
\hline Segitiga & $\begin{array}{l}\text { Lurus } \\
\text { Tepat }\end{array}$ & $\begin{array}{l}\text { Lurus } \\
\text { tepat }\end{array}$ & Paham & Paham \\
\hline $\begin{array}{l}\text { Segi } \\
\text { empat }\end{array}$ & $\begin{array}{l}\text { Lurus } \\
\text { tepat }\end{array}$ & $\begin{array}{l}\text { Lurus } \\
\text { tepat }\end{array}$ & paham & paham \\
\hline $\begin{array}{l}\text { Lingkar } \\
\text { an }\end{array}$ & $\begin{array}{l}\text { Gradasi } \\
\text { Arsiran } \\
\text { Hapus } \\
\text { mengulang }\end{array}$ & $\begin{array}{l}\text { Arsiran } \\
\text { Hapus } \\
\text { mengul } \\
\text { ang }\end{array}$ & Sulit & paham \\
\hline $\begin{array}{l}\text { Lonjong } \\
\text { Gradasi } \\
\text { Arsiran } \\
\text { Hapus } \\
\text { mengulang }\end{array}$ & $\begin{array}{l}\text { Arsiran } \\
\text { Hapus } \\
\text { mengul } \\
\text { ang }\end{array}$ & Sulit & paham \\
\hline $\begin{array}{l}\text { Penggab } \\
\text { ungan } \\
\text { Segitiga } \\
\text { dan } \\
\text { segiemp } \\
\text { at }\end{array}$ & $\begin{array}{l}\text { Lurus } \\
\text { Tepat }\end{array}$ & $\begin{array}{l}\text { Lurus } \\
\text { Tepat }\end{array}$ & Paham & Paham \\
\hline $\begin{array}{l}\text { Penggab } \\
\text { ungan } \\
\text { lingkara } \\
\text { dan } \\
\text { lonjong }\end{array}$ & $\begin{array}{l}\text { Gradasi } \\
\text { Arsiran } \\
\text { mengulang }\end{array}$ & $\begin{array}{l}\text { Hapus } \\
\text { mengul } \\
\text { ang }\end{array}$ & Sulit & Paham \\
\hline
\end{tabular}

Komentar seringkali terjadi baik dengan merasa terjadi kesalahan gambar, harus menghapus, mengulanginya kembali, beberapa terjadi ketidak percaya dirian, bahkan beberapa kekecewaan terjadi. Beberapa komentar sering diajukan, lonjakan interupsi dengan gestur tubuh yang seakan-akan mengalami kesulitan juga terjadi. Peneliti melihat bahwa garis lengkung ini membuat mereka mempersepsikan gambaran yang jauh dari pandangan mereka tentang bentuk, seperti melihat sesuatu yang baru atau mungkin sesuatu yang jauh di luar jangkauan mereka.

\section{Model Kombinasi}

Pada model kombinasi yang dilakukan di sesi ketiga, pembelajaran yang dilakukan adalah menggambar sebuah mata. Penggambaran ini melanjutkan 
dari proses sesi pertama dan kedua tentang menggambar garis lengkung serta lingkaran. Proses penggambaran oleh siswa didik tidak banyak terjadi kesulitan, walaupun beberapa siswa harus menghapus dan mengulangi gambar mereka. Sepertinya siswa yang mengulangi gambar tersebut ingin memberikan kesan yang sempurna dalam gambar yang diolah. Hal ini menunjukan bahwa proses motorik dan persepsi visual siswa didik mempunyai peningkatan dalam pemahaman dan ingatan mereka tentang bentuk gambar yang sudah dilakukan. Hal serupa juga ditampilkan dalam penggambaran model kedua, yakni gambar gua dengan beberapa model bentuk garis lengkung yang berpadu dengan garis yang sedikit abstrak.

Kesulitan penggambaran terjadi pada sesi menggambar wajah dengan kombinasi bentuk yang beragam seperti model garis vertikal dan horisontal, model bentuk lingkaran, dan penggabungan terhadap gambar model mata yang sebelumnya sudah dibuat. Tekanan gambar terjadi pergeseran dan beberapa tidak sempurna. Sepertinya dalam penggambaran lingkaran memberikan kesulitan tersendiri oleh peserta didik. Beberapa komentar "susah", "bingung", ataupun "bagaimana caranya?” seringkali terlontarkan. Walaupun demikian tidak memakan waktu yang lama untuk mengadaptasi arahan pendidik yang sudah memberikan pengulangan cara menggambar.

Hal tersebut juga membangun interupsi oleh beberapa pengajar, misalnya bapak Ubaidillah (2019) menghimbau para peneliti untuk lebih pelan, santai, serta memberikan gambaran-gambaran yang mudah, walaupun bentuk kemudahan yang dimaksud tidak diberikan secara konkrit. Hal ini bisa menunjukan bahwa persepsi "gambar mudah" untuk penyandang tunagrahita tidak semudah individu normal pada umumnya. Jika kita kembali pada penggambaran sebelumnya, yakni garis dan bentuk model sederhana, para siswa dapat dengan mudah memahami makna dan mengolah dengan cukup cepat, walaupun beberapa model seperti lengkungan dan lingkaran menjadi model yang tersulit.

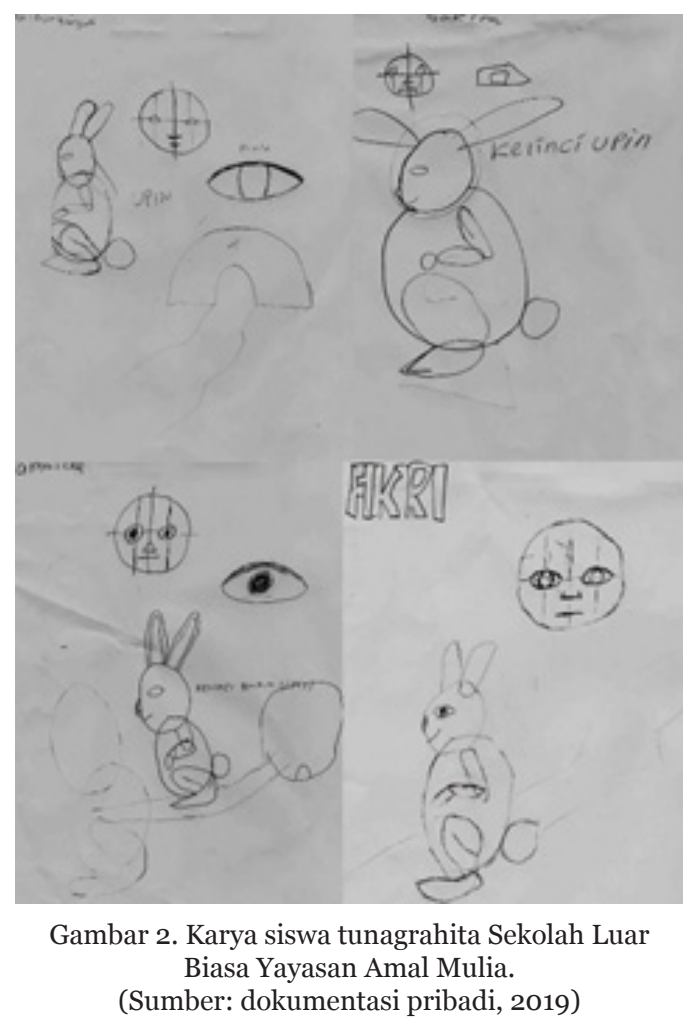

Menggambar model terakhir yang dilakukan adalah menggambar kombinasi bentuk menjadi seekor hewan kelinci. Komponen bentuk pola gambar lebih condong kepada bentuk lingkaran seperti bagian wajah, mata, tubuh, kaki, tangan dan ekor. Pada tahap ini menjadi kesulitan yang terbesar oleh peserta didik dalam mengolahnya. Beberapa kali kesalahan, penghapusan dan perbaikan kembali gambar menjadi sempurna memakan waktu yang cukup lama. Kelelahan dan hilangnya konsentrasi pun terjadi. Melihat hal tersebut, pendidik mencoba berkomunikasi dan membangun motivasi peserta didik untuk mencoba lagi hingga selesai. Walaupun dengan bentuk motivasi yang cukup intens, ada beber- 


\section{Arief Ruslan ${ }^{1}$ \\ Arif Nur Hidayat ${ }^{2}$ Archita Desia Logiana ${ }^{3}$}

Persepsi Visual Penyandang Tunagrahita: Studi Deskriptif Olah Gambar Pada Sekolah Luar Biasa Yayasan

Amal Mulia apa peserta didik yang menyerah dan tidak melanjutkan gambarnya secara utuh. Bagi mereka penggambaran bulat yang cukup banyak, padat dan bermacam-macam sepertinya membuat pemaknaan terhadap bentuk seakan-akan menguras tenaga serta pikiran. Komentar-komentar tentang betapa sulitnya membuat peneliti memahami bahwa persepsi visual siswa terhadap multiple shapes tersebut mengguncang sensor motorik dengan makna yang lain, misalnya, ketika penggambaran antara mata dengan tubuh kelinci dianggap sesuatu yang sama dengan posisi yang sama pula.

Prosesi pengolahan gambar secara keseluruhan memperlihatkan adanya fase dan tingkat kemudahan dan kesulitan. Secara deskriptif, pengolahan dihadirkan melalui olahan gambar para siswa dan komentar-komentar yang terbangun. Bentuk garis lurus sepertinya menjadi kemudahan-kemudahan para siswa dalam mengolahnya, fase garis lurus (vertikal serta horisontal) mudah untuk ditarik para siswa dengan alat gambarnya. Begitu pula gabungan antar garis yang dijadikan bentuk lain seperti segitiga, segiempat, serta gabungan segitiga dan segi empat. Tingkat kesulitan mulai hadir pada penggambaran lingkaran dan lonjong. Dengan bentuk garis yang setidaknya memberikan dampak garis yang tidak sesuai, penghapusan, ataupun komentar-komentar yang diucapkan mendeskripsikan bentuk tersebut menjadi hal yang dianggap sulit. Fase kemiripan gambar juga menjadi problematika tersendiri. Seperti penggambaran gabungan antara lingkaran dengan lonjong juga terjadi kemiripan. Hali ini seperti yang diuraikan oleh Chamel,et al., (1985) dengan eksperimen kemiripan gambar membuat pudarnya persepsi visual antar dua bentuk yang mirip tersebut.

Penggambaran model kombinasi ini para peserta didik setidaknya merasa puas dengan apa yang sudah digambarnya. Gambar-gambar yang sudah dibuat tidak lepas dari kebanggaan mereka dengan menunjukan hasil kepada para guru, teman, juga para pendidik penelitian ini. Candaan kepada teman-teman lainnya pun ikut bagian, kadangkala para peserta didik menanyakan apa yang digambar temannya dengan tawanya. Tidak terlihat ada keraguan, malu, dan ketidakpercayadirian mereka untuk menampilkan karya-karya yang sudah diolah.

Melihat hal tersebut, peneliti menganggap bahwa pada pelatihan pengolahan yang dilakukan oleh instruktur kepada mereka mungkin membangun persepsi visual melalui pengalaman- pengalamannya. Bisa saja garis-garis yang pernah mereka pelajari dari pembelajaran pengenalan huruf memungkinkan motorik sensor mereka untuk mengingat kembali. Tetapi pada gambar yang lain kemungkinan besar belum terjamah atau belum fokus untuk dipelajari secara seksama dan intens, sehingga saran bagi peneliti pembelajaran tentang bentuk-bentuk baru perlu sekali untuk terus dilanjutkan.

\section{Diskusi}

Persepsi visual tidak hanya melihat objek dengan jelas saat melihat ke dalam sesuatu yang statis, dinamis, atau bahkan lebih kompleks, tetapi juga mencakup penglihatan. Melihat beberapa rangsangan yang berubah seiring waktu dan proses membantu peserta didik menafsirkan arti dan relevansi rangsangan tersebut. Proses ini memainkan peran sebagai penghubung ke otak yang menafsirkan atau memberi makna informasi ini (Kurtz, 2006).

Dalam pelatihan menggambar yang diberikan melalui beberapa model memperlihatkan bahwa garis-garis solid terpisah tidak memberikan dampak yang signifikan, bahkan para siswa mampu memahami dan mengolah gambar dalam bentuk jadi. Begitu pula koneksi antar 
garis lurus yang membentuk model solid seperti segitiga dan segiempat. Pengolahan gambar tersebut mempersepsikan garis yang dominan mudah dilakukan, dengan tarikan yang lurus memungkinkan para siswa dengan mudah memroses gaya visual tersebut. lain halnya dengan garis yang dominan dengan bentuk yang lengkung baik lengkungan, lingkaran, atau lonjong. Persepsi yang hadir membangun pertanyaan, kesusahan, atau mungkin suatu model yang cukup asing bagi mata mereka, sehingga makna terhadap garis tersebut ada noise dalam berkomunikasi melalui visual.

Bagi para penyandang tunagrahita di SLBYAM proses menggambar bentuk dan model dasar tidak semuanya menjadi hambatan, walaupun beberapa kesulitan olah terjadi, tetapi pemahaman dan pengolahan menuju sempurna membuat gaya visual yang dihadirkan membangun motivasi mereka. Dengan proses pelatihan menggambar ini tentunya menjadi bahan penting sebagai pembelajaran visual penyandang tunagrahita. Tentunya para pendidik bisa memahami seperti apa pola gambar yang dapat menyulitkan para anak-anak tunagrahita, sehingga perlunya pembelajaran lanjutan untuk dapat memberikan pemahaman tentang bentuk dan model tersebut. Sebagai bentuk persepsi visual yang dihadirkan oleh anak-anak tunagrahita, khususnya tipe sedang, perlu menjadi perhatian yang penting dan diberikan keberlanjutan dalam motorik kasar visual.

\section{Kesimpulan}

Dengan proses penggambaran tersebut, peneliti mendapati bahwa kesulitan-kesulitan yang sering terjadi ketika proses penggambaran lingkaran sempurna. Anak-anak tunagrahita sepertinya cukup berat dalam penggambarannya tersebut, hal ini dapat dilihat bahwa penggambaran lingkaran sempurna me- makan waktu yang cukup lama, terjadinya penghapusan dan penggambaran ulang. Terlebih lagi dalam pengolahan model gabungan antar lingkaran. Persepsi visual anak-anak tunagrahita untuk melihat bentuk lingkaran dianggap sesuatu yang sangat berat, sulit, dan bahkan membuat mereka tidak dapat melanjutkan pengolahannya. Walaupun demikian, beberapa siswa terus melanjutkan sampai mencapai kesempurnaan pada persepsi mereka.

Pada dasarnya, penelitian ini masih tahap awal untuk melihat tentang persepsi, menghadirkan, serta memperlihatkan gambar-gambar bentuk seperti apa saja yang mudah hingga paling sulit menurut pandangan siswa tunagrahita. Peneliti berharap dengan penelitian awal ini dapat menjadi keberlanjutan kepada peneliti- peneliti selanjutnya untuk meneliti bagian-bagian yang belum terjamah dan melengkapi kekurangan atas penelitian ini.

\section{Acknowledgement}

Peneliti mengucapkan terima kasih kepada ibu Nurul Mukarromah, S.Pd, sebagai kepala sekolah YBLAM yang telah memberikan kesempatan dalam penelitian ini. Ucapan terima kasih juga saya lantunkan kepada teman dan kolega yang memberikan arahan, masukan, serta referensi sebagai landasan penelitian. Tidak lupa kepada pengelola dan reviewer artikel yang juga memberikan tanggapan positif melalui kritik serta saran yang membangun kepada peneliti.

\section{Referensi}

Alenizi, M. A. K. (2019). Effectiveness of a program based on a multi-sensory strategy in developing visual perception of primary school learners with learning disabilities: A contex- 
tual study of Arabic learners. International Journal of Educational Psychology, 8(1), 72-104. https://doi. org/10.17583/ijep.2019.3346

American Psychiatric Association. (2013). Diagnostic and statistical manual of mental disorder (5th ed.). Washington, DC: American Psychiatric Publising.

Barbour, B. (2014). Introducing qualitative research: A student's guide (2nd ed.). London, England: Sage.

Chamel, E. N., Goyos, C., Saunders, M., \& Saunders, R. (1985). The Analysis of Verbal Behavior 1 Stimulus equivalence paradigms have been used to study complex human behavior, and to effectively teach academic and other socially relevant skills to individuals with or without learning disabilities (i.e Teaching Manu. 1-13.

Creswell, W. J. (2014). Penelitian Kualitatif \& Desain Riset: Memilih di Antara Lima Pendekatan. Edisi Bahasa Indonesia 2014. Yogyakarta. Pustaka Pelajar.

Darnanta, I. W., Pradnyana, I. M. A., \& Agustini, K. (2020). Development of mathematics interactive learning media with gamification concepts for mentally disabled students. Journal of Physics: Conference Series, 1516(1). https://doi.org/10.1088/17426596/1516/1/012043

Delphi, B. (2005). Anak Berkebutuhan Khusus. Bandung. PT. Rosda Karya.

Erim, G., \& Caferoğlu, M. (2017). Determining the Motor Skills Development of Mentally Retarded Children through the Contribution of Visual Arts. Universal Journal of Educational Research, 5(8), 1300-1307. https:// doi.org/10.13189/ujer.2017.050803

Fox, R., \& Oross, S., III. (1988). Deficits
Persepsi Visual Penyandang Tunagrahita: Studi Deskriptif Olah Gambar Pada Sekolah Luar Biasa Yayasan Amal Mulia

in stereoscopic depth discrimination by mildly mentally retarded adults. American Journal on Mental Retardation, 93, 232-244.

Garje, M., Vishnu, D., Rashmi, Y., Arpita, A., \& Maninder, S. (2015). Study of the visual and perceptual problems in children with learning disability. Indian Journal of Basic and Applied Medical Research, 4(3), 492-497.

Glaw, X., Inder, K., Kable, A., \& Hazelton, M. (2017). Visual Methodologies in Qualitative Research: Autophotography and Photo Elicitation Applied to Mental Health Research. International Journal of Qualitative Methods, 16(1), 1-8. https://doi. org/10.1177/1609406917748215

Kurtz, L. (2006). Problems with perception in the visual children with the ADHD and other learning disabilities: A guide for parents and professional, Jessica Kingsley Publishers: London and Philadelphia.

Louk, M. J. H., \& Sukoco, P. (2016). Pengembangan media audio visual dalam pembelajaran keterampilan motorik kasar pada anak tunagrahita ringan. Jurnal Keolahragaan, 4(1), 24. https://doi.org/10.21831/ jk.v4i1.8132

Mahmoud, A., Alnahdi, G. (2014). The effectiveness of remedial education computer aided in the development of the skills of visual perception of pupils with learning difficulties in the second grade primary. Journal of Special Education, 8, 101-147.

Mulyana, D. (2018). Metodologi Penelitian Kualitatif: Paradigma Baru Ilmu Komunikasi dan Ilmu Sosial Lainnya. Bandung. PT Remaja Rosdakarya Offset.

Pardimin., Widodo, S. A., (2017). Development Comic Based Problem Solving 
in Geometry. Int. Electron. J. Math. Educ., vol. 12, no. 3, pp. 233-241.

Pieters , S., Desoete , A., Roeyers , H., Vanderswalmen, R., \& Waelvelde, $H$. (2012). Behind mathematical learning disabilities: what about visual perception and motor skills? Individual Differences in learning, 22(4), 498-504. doi: http://dx.doi.org/10.1016/j.lindif.2012.03.014

Webb, T. E. (1972). Stereoscopic contour perception in mental retardation. American Journal of Mental Deficiency , 76, 699- 702 . 